as in the Civil Service; but also by giving facilities for those measures such as reform of the law of libel, which by promoting free public discussion make for the formation of enlightened public opinion on affairs of the day. Nor should it be forgotten that measures which promote the efficiency of government have a direct effect on productivity and efficiency in other spheres, apart altogether from any saving those measures themselves directly secure in man-power or materials.

\section{THE POTATO AND SOCIAL DEVELOPMENT}

The History and Social Influence of the Potato By Redcliffe N. Salaman; with a chapter on Industrial Uses by W. G. Burton. Pp. xxiv $+685+32$ plates. (Cambridge : At the University Press, 1949.) 50s. net.

THERE is a tendency nowadays to look unfavour ably on any book which has for its subject the production and the supply of food. This is perhaps not so much because we are all acutely food conscious, but rather because we have come to regard food in the prosaic light of calorific content. That admirable principle, "a little of what you fancy does you good", can no longer be applicable in an age of restricted choice. Our appetites have had perforce to be modified by the limitation of our resources. Necessity has become our master and the written word the means of persuading us, probably, against our better judg. ment, that though we may no longer fancy what we eat, what, in fact, we do eat may still be good for us because it contains so many units of stored-up energy. If, therefore, the literature about food reflects in some degree the economic background of the period in which it is written, we, who live in 1950 , may be excused if we show a preference for nostalgic memories and $\mathrm{a}$ certain disinclination to read about foods which we are forced to eat in order to sustain our bodies but which leave our minds unaffected by their dullness.

A book about the potato, therefore, might be expected to evoke no more than a passing interest in a very common article of diet. We are more than reasonably certain about the conditions governing its cultivation, and accept without question its value as a food. It is difficult for the modern mind to realize that there was ever a time in our history when the food problem had to be faced without potatoes, when food scarcity had to be reckoned in terms of corn, pulses and green vegetables. The comparison needs no further elaboration. The potato has become something more than a staple food, and Dr. R. N. Salaman has given us a precise and scientific study of it in organic relation with our social history.

Let it be said at once that not all economic and social historians will readily accept Dr. Salaman's interpretation of the social influence of his subject. Our standard works of reference in economic and social history assume a man-controlled world. They deal primarily with the ways and means by which we have, through our utilization of the factors of production, built up for ourselves a highly complex economic and social system. In this system there is a continuous struggle to equate the supply of food and raw materials with an insatiable and oftentimes a capricious demand. Dr. Salaman has shown us that there are valuable conclusions to be drawn from a differont approach, and that the scientific analysis of an abjective investigator can be made to throw light into dark places.

Dr. Salaman's interest in the potato began with genetics, morphology and pathology. In course of time his attention was turned to the study of the social and economic reactions on mankind of the adoption of this cheap and easily produced foodstuff. But "The History and Social Influence of the Potato" contains much more than an interesting treatment of what otherwise might have been a dull subject. It is a work of profound and accurate scholarship, the product, over long years, of patient and careful search. Side by side with the history of the potato, its adoption by man and its spread throughout the world, is a study of the influence which it has exerted on the social structure of those people who accepted it as a staple article of diet. It is an attempt "to study reactions set up between a plant which under cultivation is relatively stable and the social environment often unstable and variable into which it has been introduced".

Against this background of changing economic development facts have been set forth about the cultivation and the acceptance of the potato. Dr. Salaman uses his sources of information with great skill, drawing upon the records of the archreologist, revealing the secrets of the archivist, and bringing us the latest information available for study. He presents us with an objective account of early cultivation in South America, of the introduction of the potato to Europe, and a reasoned statement backed by much evidence of the economic importance of the crop as a means of sustenance and income to the Scottish and Irish peasant in the eighteenth and the nineteenth centuries. The history of the potato famine in Ireland in the 1840's is put into perspective ; the consequences of that famine are treated without bias. Such chapters as "The Potato in the Realm of Art" and "The Potato of Shakespeare and the Jacobeans" add to the evidence, if that were needed, of Dr. Salaman's comprehensive treatment, and serve to make the book a mine of information about a host of unusual but nevertheless related topics.

The general reader as well as the specialist may derive profit and pleasure from a reading of this book. They may turn to its pages without foreboding. The potato plays an increasingly important part in our daily life, and, whether we are food conscious or not, or whether we regard it potentially as so many calories, we cannot fail to be indebted to Dr. Salaman for his work on its history and its social influence.

Francis E. Hyde

\section{DISEASES OF THE TOMATO}

\section{Tomato Diseases}

An Illustrated Guide to their Recognition and Control. By Prof. Robert McKay. Pp. viii $+108+43$ plates. (Dublin : At the Sign of The Three Candles, 1949.) $21 s$.

7 HIS useful book is intended primarily for growers, instructors in horticulture, and as a handy work of reference for nurserymen, seedsmen and others who have to deal with the various disorders of tomato plants. Unlike many treatises on plant diseases, which are often confined to troubles caused by parasitic organisms, fungi in particular, it is gratifying to find that, in this small but comprehensive work, maladies due to other agencies actually outnumber the former. The author has described twelve fungal, two bacterial, seven virus and fifteen non-parasitic 